\title{
Application of Thermal Remote Sensing technique for mapping of ultramafic, carbonate and siliceous rocks using ASTER data in Southern Rajasthan, India
}

\author{
Ronak Jain*, Harsh Bhu and Ritesh Purohit \\ Department of Geology, Faculty of Earth Sciences, Mohanlal Sukhadia University, Udaipur 313 001, India
}

In the present study, thermal remote sensing technique and ASTER data have been used to delineate ultramafic, carbonate and siliceous rocks. The study gains importance as mineralized carbonate and ultramafic rocks are present in the southern region of Rajasthan, India between Udaipur and Dungarpur districts. The rocks in the study area include phyllites, mica schist, chlorite schist, quartzite, dolomite, granite, granitoids, gneiss and intrusive serpentinite. ASTER thermal bands were used to map ultramafics, siliceous and carbonate rocks on a scale of $1: 380,000$. Delineation of ultramafics was done using MRI-AV and MI-N indices, however the former provided a more informative map compared to the latter. QRIAV, QI-N and QI-RH indices were used for mapping siliceous rock. QI-RH provided a more informative map compared to QRI-AV and QI-N. The index used for carbonate rocks was $\mathrm{CI}-\mathrm{N}$, but this did not provide a satisfactory map.

Keywords: ASTER TIR, carbonate and siliceous rocks, thermal indices, thermal remote sensing, ultramafics.

MAJORITY of oxides-hydroxides, clay and carbonate minerals reflect spectral absorption in the visible near infrared (VNIR) and shortwave infrared (SWIR) regions $^{1,2}$, whereas major rock-forming minerals such as quartz (silicates) and orthoclase/plagioclase (feldspar) do not represent any kind of spectral absorption features. The thermal infrared (TIR) region is beneficial for the discrimination of such kinds of minerals based on variances in the emissivity spectra. Atomic and molecular vibrations are the main factors responsible for changes in the emissivity spectra of different minerals. In the TIR spectral domain, vibrational spectroscopy provides ample amount of information about minerals due to variation in emissivity, because minerals have a different chemical composition and molecular structure ${ }^{2,3}$. Majority of the silicate minerals show variation in vibrational energy

*For correspondence. (e-mail: jainronak75@yahoo.in)

pattern of the $\mathrm{Si}-\mathrm{O}$ bond $^{1,4}$, which reflects variation in the emissivity spectra of these minerals and is responsible for shifting of emissivity minima of silicate-bearing rocks in TIR spectra ${ }^{2,5,6}$. TIR spectroscopy is useful for mapping of geological materials which exhibit vibrational absorption in the spectral range 3-50 $\mu \mathrm{m}$ (refs 2, 3 and 5) like silicate as well as carbonate-rich rocks with diagnostic emissivity features in the TIR region ${ }^{3,5-11}$. TIR spectroscopy is less common compared to reflectance spectroscopy to map and delineate various kinds of rocks and minerals. This is due to the fact that very few hyperspectral (spectral observation in contiguous channels) and multispectral space-borne sensors are operative in the TIR domain. This is, in turn, related to poor signal-tonoise (SNR) ratio of data recorded by the thermal channels within the TIR domain ${ }^{12}$. This is another hindrance for using contiguous spectral bands with finer spectral resolution to detect subtle variations in thermal emissivity within the TIR wavelength range.

The present study aims to evaluate the thermal remote sensing technique for identification and demarcation of ultramafic, carbonate and siliceous rocks in the study area using different thermal mineral indices by analysing ASTER data of Terra satellite. It also aims to compare better suitability of the indices for the region. Different varieties of rock like quartzite, carbonate, phyllite, schist and serpentinite are present in the region. So it is assumed that thermal spectroscopy will provide a better understanding of the distribution pattern in this region.

\section{Geology}

The study area is in the southern region of Rajasthan, extending between Udaipur and Dungarpur districts (Figure 1). The litho-units consists of the Archaean basement rocks of the Banded Gneissic Complex (BGC), Proterozoic supracrustals of the Aravalli Supergroup and intrusives $^{13-17}$ (Table 1). The BGC comprises of Sarara Inlier and Kherwara Inlier granitoids and the Aravalli Supergroup comprises of conglomerate, dolomite, quartzite, mica schist and phyllite rocks. Intrusives are mainly 


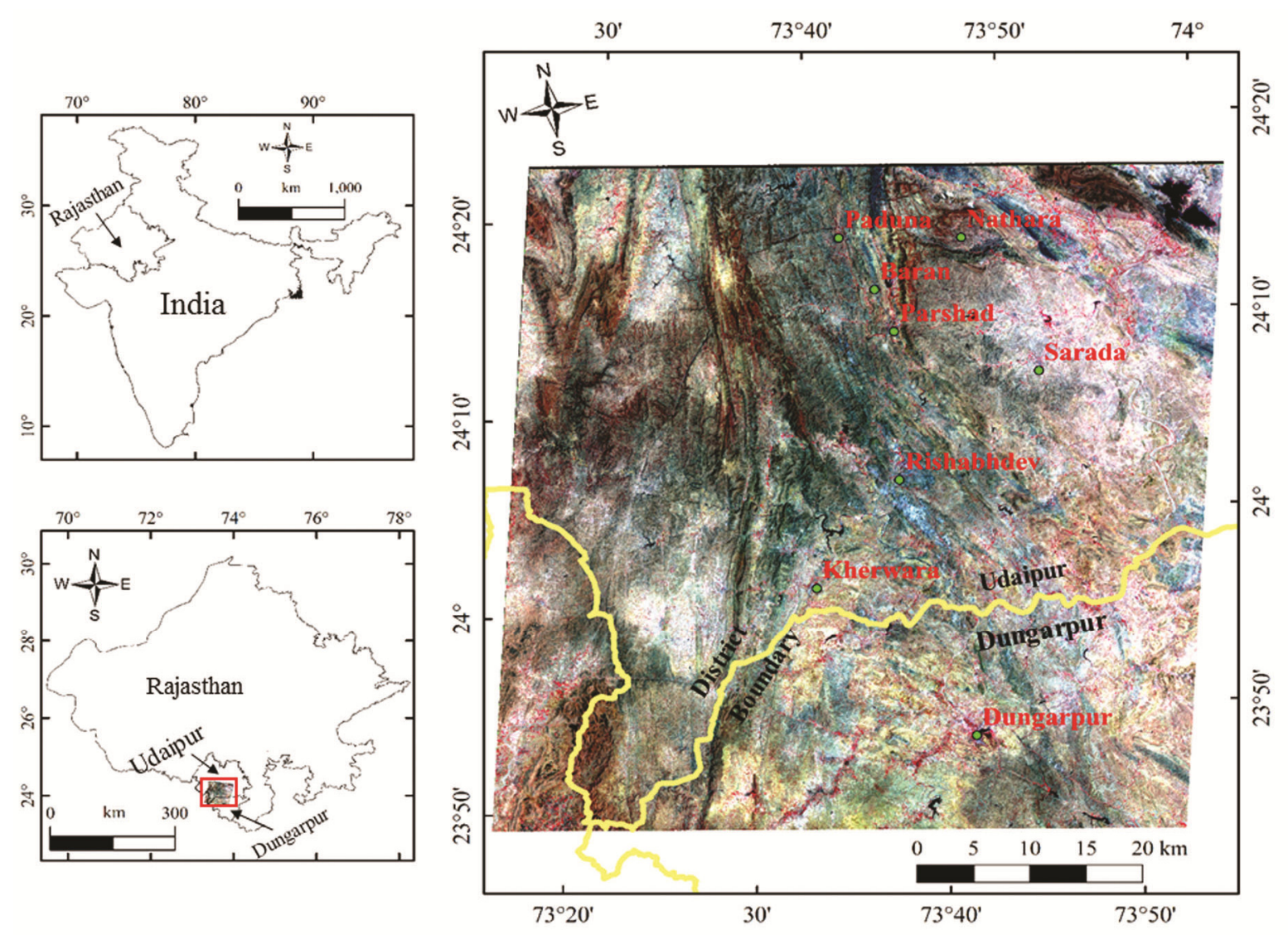

Figure 1. Map showing location of the study area in Rajasthan, India, and imagery extended from south of Udaipur to Dungarpur.

Table 1. Stratigraphic distribution of geological litho-units of the study area (modified after Gupta et al. ${ }^{13}$ )

\begin{tabular}{|c|c|c|c|}
\hline Age & Supergroup & Group & Lithology \\
\hline \multirow[t]{4}{*}{ Proterozoic } & \multirow{2}{*}{\multicolumn{2}{|c|}{$\begin{array}{l}\text { Udaipur granites and gneisses (intrusion) } \\
\text { Rakhabdev Ultramafic Suite (intrusion) }\end{array}$}} & Granites, Gneiss \\
\hline & & & Serpentinites \\
\hline & \multirow[t]{2}{*}{ Aravalli } & Udaipur & $\begin{array}{l}\text { Phyllites, slates with interbands of quartzite, dolomite and } \\
\text { meta-dolerite, quartzite and variant facies of dolomite, } \\
\text { pebbly greywacke, phyllite, carbonaceous phyllite with } \\
\text { minor intercalations of quartzite and dolomite }\end{array}$ \\
\hline & & Debari & $\begin{array}{l}\text { Dolomite, mica schist and phyllite with subordinate calcareous } \\
\text { and carbonaceous rocks, metaconglomerate, meta-arkose and } \\
\text { quartzite, basic volcanic-sedimentary rocks (hornblende-- } \\
\text { actinolite schist and chlorite-actinolite schist), gritty and } \\
\text { conglomeratic quartzite }\end{array}$ \\
\hline Archean & Bhilwara & & Banded gneissic rocks, migmatites and schist \\
\hline
\end{tabular}

serpentinites $^{13}$. The study area is known for lead-zinc mineralization hosted by dolomites of the Middle Aravalli Group $^{15}$.

\section{Materials and method}

Advanced spaceborne thermal emission and reflection radiometer (ASTER) launched on-board by the earth observation satellite (EOS), Terra, is a multi-spectral sensor system $^{18,19}$. ASTER has three bands in the VNIR domain, six bands in the SWIR domain and five bands in the TIR domain (band nos 10-12). ASTER data have been extensively used for mapping few significant types of surface mineralization signatures associated with hydrothermal alteration zones and oxidation capping of supergene enrichment deposits based on the diagnostic absorption features of different clay, carbonate, aluminium-iron hydroxide minerals in the VNIR-SWIR domain ${ }^{11,18-20}$. 


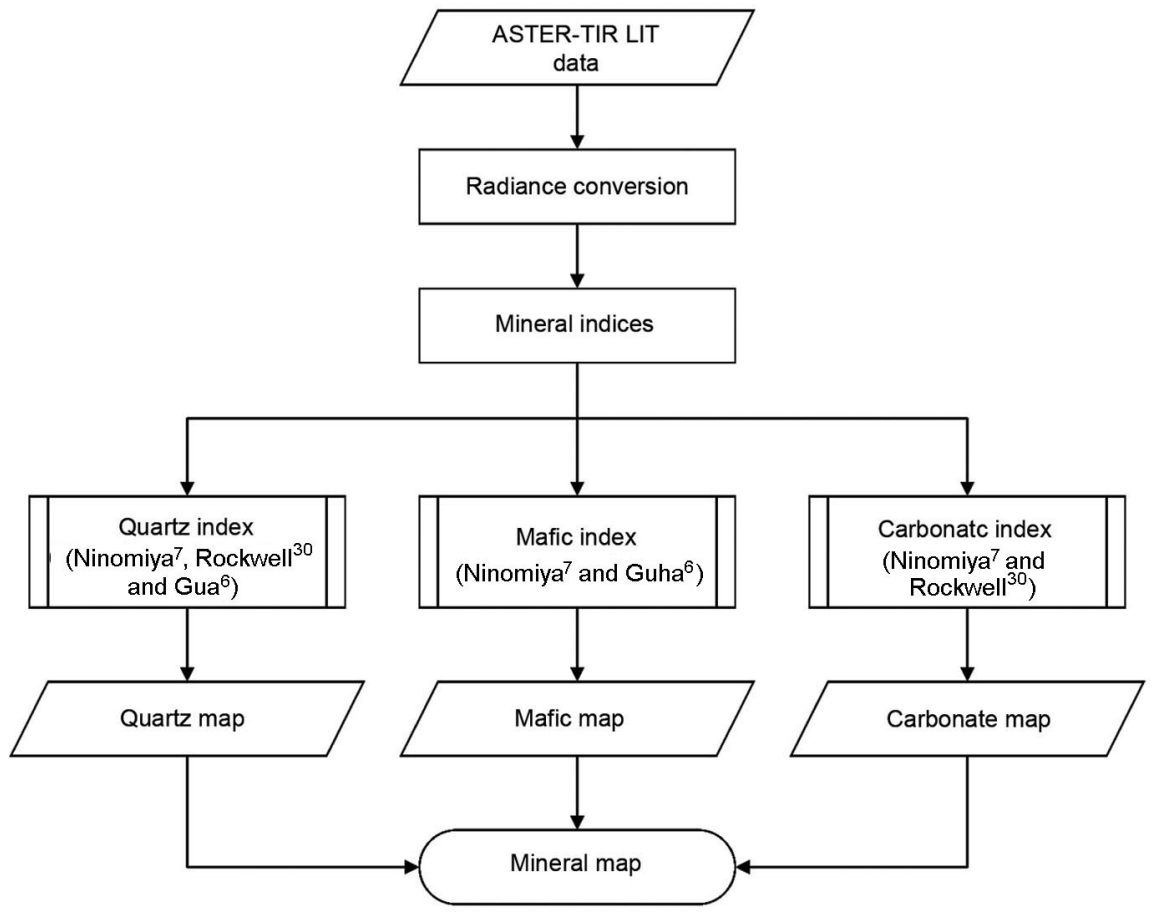

Figure 2. Overall methodology adopted to process the ASTER-TIR data for preparation of different index maps.

Table 2. Technical specifications of the ASTER L1T data

\begin{tabular}{lcccccc}
\hline Granule ID & Sensor & $\begin{array}{c}\text { Band } \\
\text { number }\end{array}$ & $\begin{array}{c}\text { Spectral } \\
\text { width }(\mu \mathrm{m})\end{array}$ & $\begin{array}{c}\text { Spatial } \\
\text { resolution }(\mathrm{m})\end{array}$ & $\begin{array}{c}\text { Radiometric } \\
\text { resolution (bits) }\end{array}$ & Valid range \\
\hline AST_L1T_0 & ASTER-TIR & 10 & $8.125-8.475$ & 90 & 12 & $0-65535$ \\
0304222003 & & 11 & $8.475-8.825$ & 90 & 12 & $0-65535$ \\
$055021 \_201$ & & 12 & $8.925-9.275$ & 90 & 12 & $0-65535$ \\
5042803151 & & 13 & $10.25-10.95$ & 90 & 12 & $0-65535$ \\
$0 \_40583$ & 14 & $10.95-11.65$ & 90 & 12 & $0-65535$ \\
\hline
\end{tabular}

The VNIR-SWIR bands of ASTER were also used for delineating few economically important rock types with spectrally sensitive minerals ${ }^{6,10,11,18}$.

ASTER L1T data used in this study were downloaded from the United State Geological Survey (USGS) EarthExplorer portal (https://earthexplorer.usgs.gov/). L1T are radiometrically and terrain corrected data (https://lpdaac. usgs.gov/documents/71/AST L1T User Guide V3.pdf) and 16-bit integer data are present in the thermal bands (bands 10-14) at $90 \mathrm{~m}$ spatial resolution. Table 2 provides more technical specifications. Band ratio and relative band depth formulation were also applied on radiance data to identify the distribution of various lithounits (rocks) in the region ${ }^{3,6-8,10,21-26}$. Figure 2 illustrates the methodology adopted.

Each pixel of the L1T data carries a digital number (DN), which is converted into calibrated radiance, i.e. $L_{\text {sen }}$ using eq. $(1)^{24,27-29}$

$$
L_{\text {sen }}^{\mathrm{i}}=\operatorname{cof}^{\mathrm{i}} \times\left(\mathrm{DN}^{\mathrm{i}}-1\right),
$$

where

$$
\begin{array}{c|c|c|c|c}
\operatorname{cof}^{10} & \operatorname{cof}^{11} & \operatorname{cof}^{12} & \operatorname{cof}^{13} & \operatorname{cof}^{14} \\
0.006882 & 0.006780 & 0.006590 & 0.005693 & 0.005224
\end{array}
$$

Guha and Vinod $\operatorname{Kumar}^{6}$ (eq. (2)), Rockwell and Hof$\operatorname{stra}^{30}$ (eq. (3)), and Ninomiya et al. ${ }^{7}$ (eq. (4)) have given the indices for the mapping of silicate rocks. These three different thermal indices have been applied on radiance data for the identification and mapping of silicate rocks.

Quartz-bearing rock index (QRI-AV)

$=($ Band 10/band 12) $\times($ band 13/band 12),

Quartz index $(\mathrm{QI}-\mathrm{RH})=($ Band 11/(band $10+$ band 12$))$ $\times($ band $13 /$ band 12$)$

Quartz index $(\mathrm{QI}-\mathrm{N})=($ Band $11 \times$ band 11$) /$

(band $10 \times$ band 12 ), 


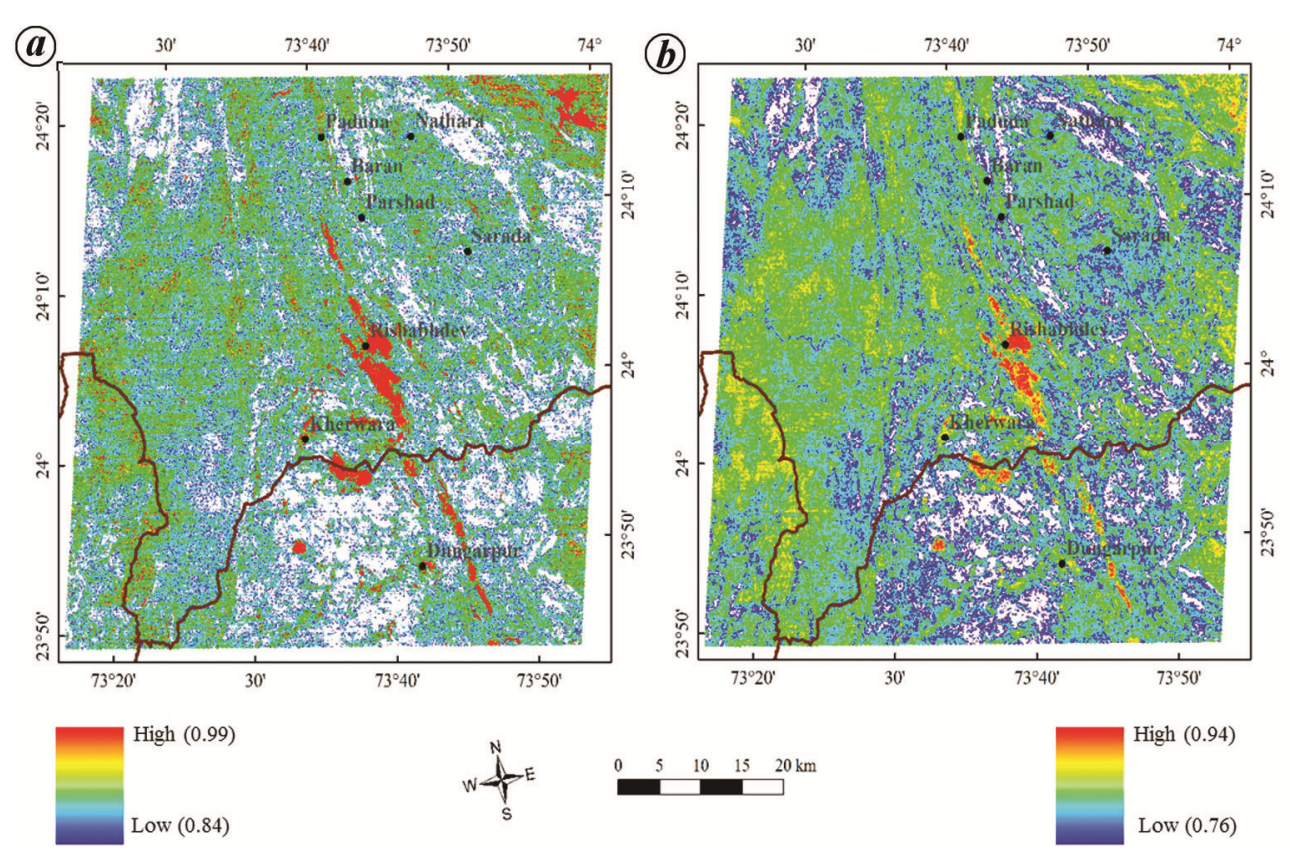

Figure 3. Mapping of ultramafic rock outcrops using thermal indices. $\boldsymbol{a}, \boldsymbol{b}$, Ultramafic maps using (a) MRI-AV and (b) MI-N. Red colour depicts the most prominent regions of ultramafic rocks.

Guha and Vinod Kumar ${ }^{6}$, and Ninomiya et $a l^{7}$ have also given indices for mapping of mafic minerals (eq. (5) and (6) respectively); these have been applied to map the ultramafics.

$$
\begin{aligned}
& \text { Mafic-bearing rock index }(\text { MRI-AV }) \\
& =(\text { Band } 12 / \text { band } 13) \times(\text { band } 14 / \text { band } 13) \text {, } \\
& \text { Mafic index }\left(\text { MI-N) }=\left(\text { band } 12 \times\left(\text { band } 14^{\wedge} 3\right)\right) /\right. \\
& \quad\left(\text { band } 13^{\wedge} 4\right) .
\end{aligned}
$$

Ninomiya et l. $^{7}$, and Rockwell and Hofstra ${ }^{30}$ have given an equation for mapping of carbonate rocks (eq. (7)). This equation has been applied to determine the availability and for mapping of carbonate rocks in the region without applying any kind of correction, i.e. atmospheric correction on the radiance data ${ }^{7}$.

$$
\text { Carbonate index }(\mathrm{CI}-\mathrm{N})=(\text { Band } 13 / \text { band } 14) \text {. }
$$

\section{Results and discussion}

The ultramafic map was developed using mafic indices of Guha and Vinod Kumar ${ }^{6}$ and Ninomiya et al. ${ }^{7}$. MRI-AV mapped the ultramafic rock outcrop with very high values in Rakhabdev region. However, in the southern zone, these indices also defined a water body as mafic outcrop on the upper right side of the area (Figure $3 a$ ). Another minor parallel belt of the ultramafic outcrop was also identified as a major rock belt in the map. MI-N mapped the ultramafic outcrop with high values confined to Rakhabdev area, while at a few places it also mapped the ultramafic outcrops with lower values (Figure $3 b$ ). Minor parallel belts of the ultramafics were not identified using this index. Ultramafic rock outcrop is more precisely mapped by MRI-AV compared to MI-N.

Quartz/siliceous rock map was developed using QRIAV, QI-RH and QI-N. All the three indices gave diverse kinds of pattern. The QRI-AV index defined siliceous rock outcrops in the region. Siliceous outcrops were marked in the outer periphery of the granitoid gneissic terrain of the Sarara Inlier. Another siliceous outcrop was identified as intrusive granitic body near Rakhabdev. This index suppresses the major mafic and carbonate rocks with certainty but low values are present in the entire region, which is a major drawback of the index (Figure $4 a$ ). QI-N index produced noisy imagery. It demarked the presence of ample siliceous rocks in the region, which is in all probability a wrong interpretation regarding the abundance of these rocks (Figure $4 b$ ). The QI-RH index demarked the siliceous rocks in the region quite precisely. In Figure $4 b$, siliceous rocks are mapped near the granitoid rock outcrops as well as close to the intrusive granite outcrops in the right lower region. This pattern of siliceous outcrops is more precise and correlatable to the published geological map of Gupta et $a l^{13}$. QI-RH decreased the values of carbonate and ultramafic outcrops and is useful to determine the distribution of siliceous outcrops (Figure $4 c$ ).

The CI-N technique used in Figure 5 to map carbonate outcrops resulted in a large amount of noise. Consequently, distinct identification of the actual carbonate outcrop was 

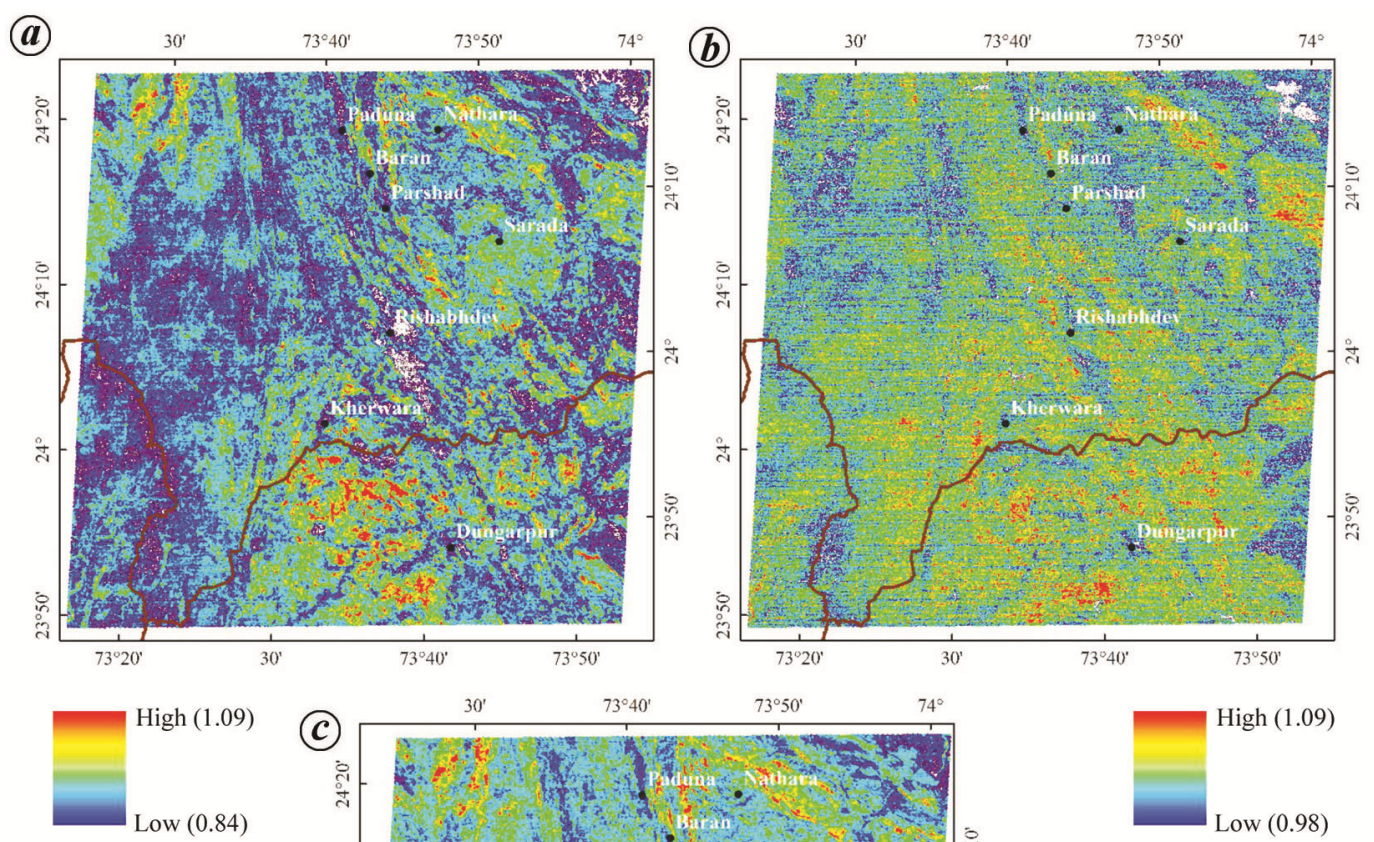

$73^{\circ} 50^{\prime}$

$74^{\circ}$
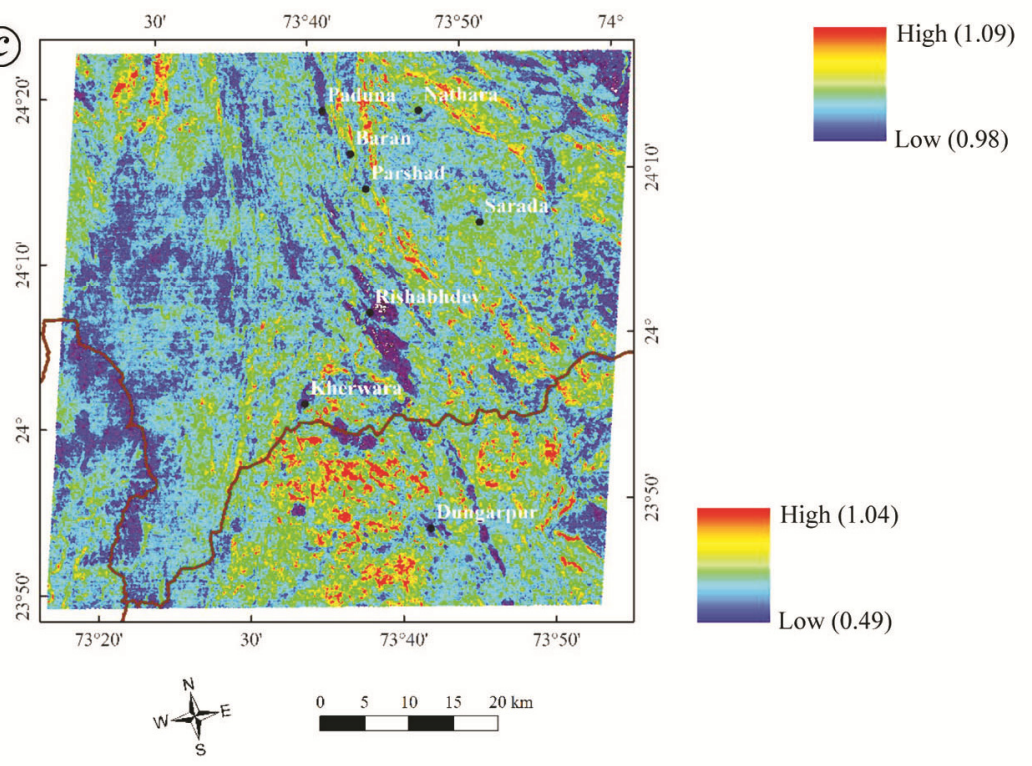

Figure 4. Mapping of siliceous rock outcrops using thermal indices. Siliceous maps using (a) QRI-AV (b) QI-N and (c) QI-RH. Red colour depicts the most prominent regions of siliceous rocks.

not possible. Carbonate outcrops gave poor interpretation due to the presence of banding noise and poor signal received at band 14 (refs 3, 31 and 32). Ultramafics and silicates also gave lower values in the carbonate map. Therefore, this was a better option for the interpretation of ultramafic and siliceous rocks (Figure 5).

A lithological map was prepared using a combination of siliceous, ultramafic and carbonate-generated maps. The map has an RGB (red, green and blue) combination of the siliceous, ultramafic and carbonate maps (Figure 6). Siliceous rock bodies (shown in dark red colour in the figure) are present as peripheral to the basement bodies. They are also parallel to the carbonate rock bodies. Few silicate rock outcrops are scattered near the ultramafics at the lower centred part (Figure 6). Ultramafic outcrops are present in bright green colour from middle to lower right. The mapped ultramafic body is highly correlative with the published map of Gupta et al. ${ }^{13}$. Carbonate bodies are visible on the map (cyan colour, Figure 6). However, majority of the study area is covered with cyan in the figure, which is not an accurate interpretation of the carbonate outcrop pattern. Nevertheless, the known carbonate occurrences are mapped accurately giving a high tone of cyan compared to others.

\section{Validation}

The prepared lithological map was validated with the help of published geological map of the region, matching of spectral signature of the rocks with library spectra and also with ground-collected data. The geological map is highly correlatable with the mapped ultramafic and siliceous rock outcrops (Figure $7 a$ and $b$ ), and also with the known carbonate occurrences. Spectral signatures matched with JHU mineral library, representing the 


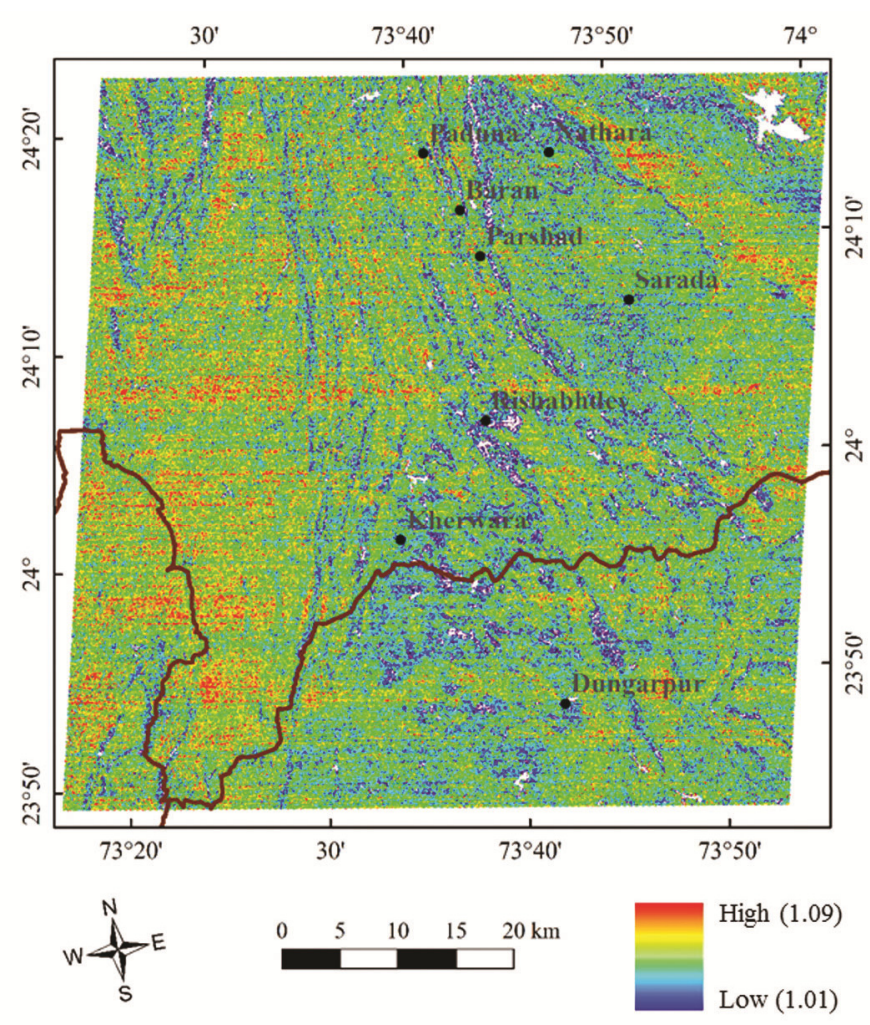

Figure 5. Carbonate map using the CI-N thermal index.

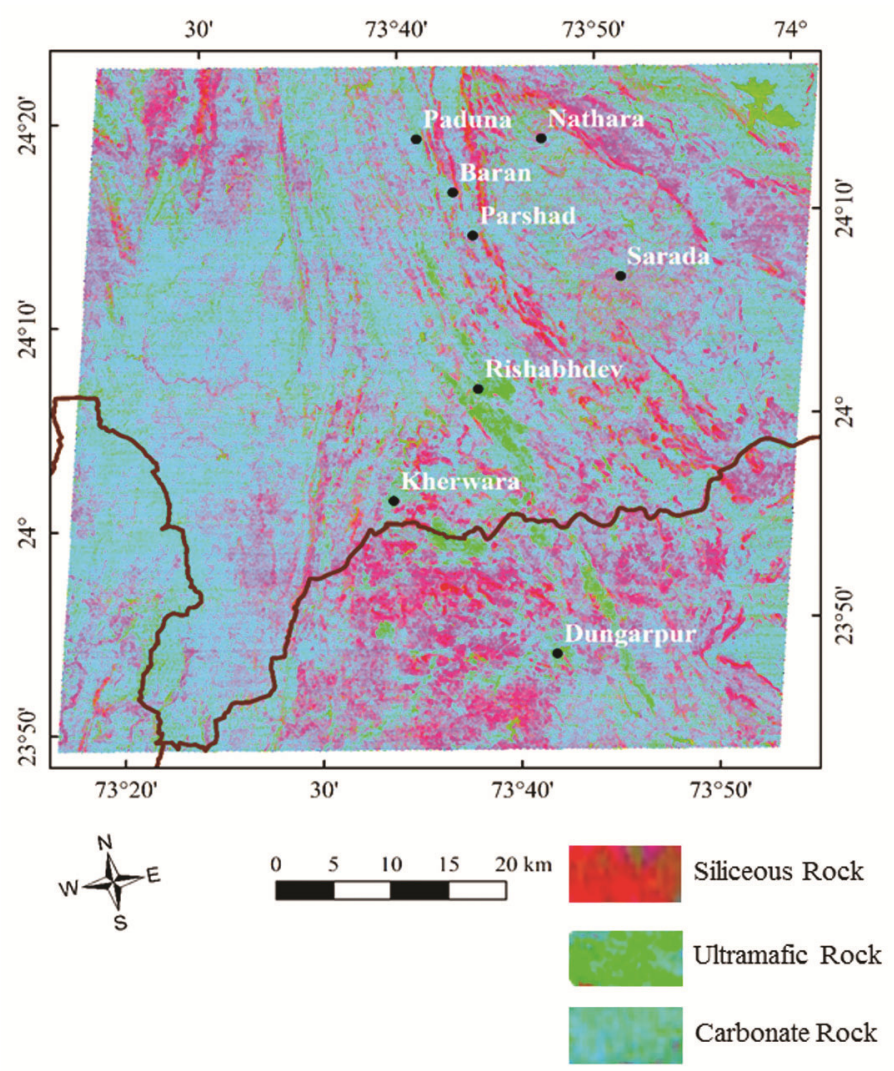

Figure 6. Lithological map of the study area generated by a combination of developed rock maps. The combination of bands are QI-RH in red, MRI-AV in green and CI-N in blue. 


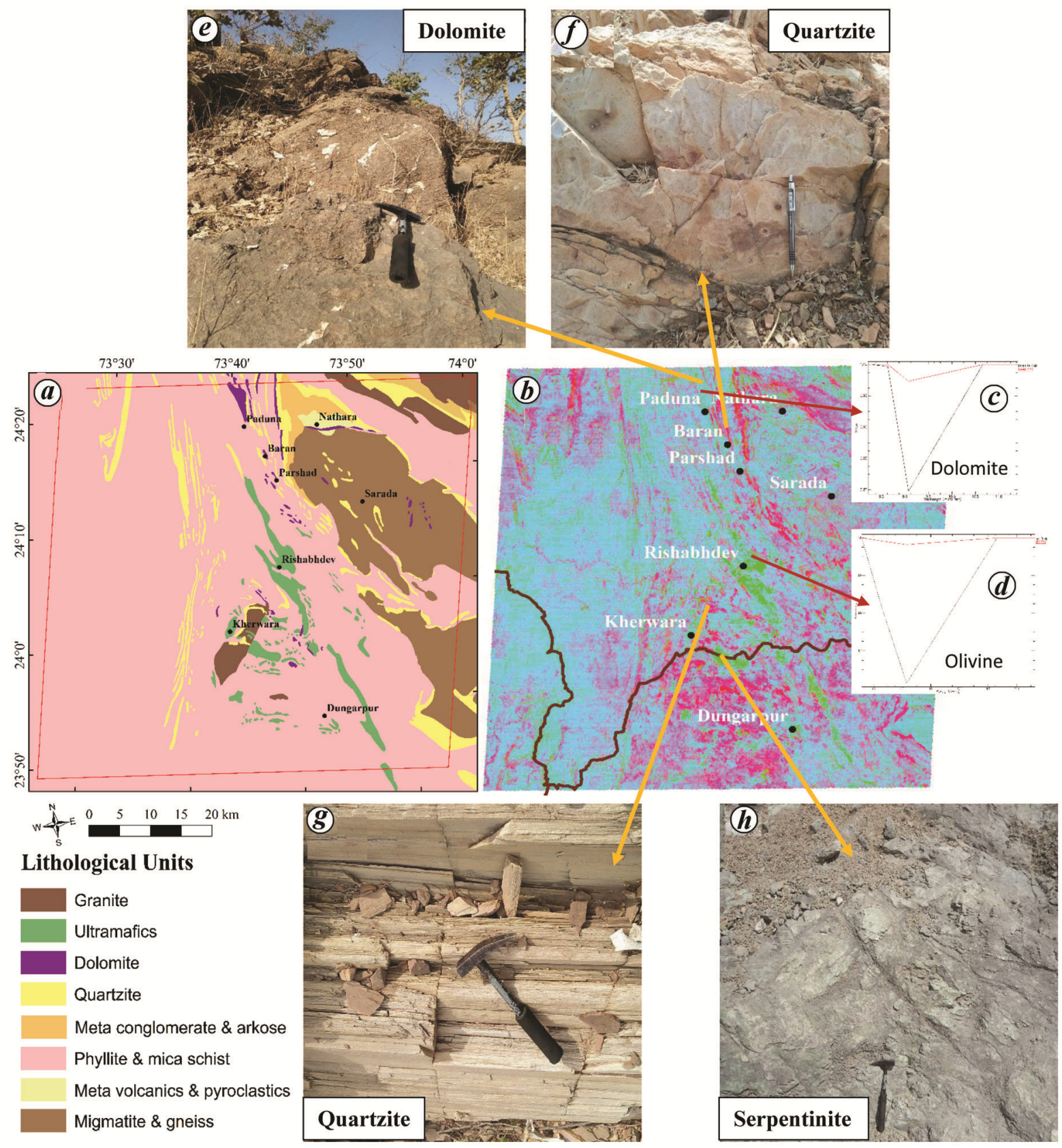

Figure 7. Validation of the generated indices map. $\boldsymbol{a}$, Published geological map of the area (red box shows the extent of the study area). $\boldsymbol{b}, \mathrm{RGB}$ of the thermal indices-generated map (see Figure 5 for legend). $\boldsymbol{c}$, $\boldsymbol{d}$, Spectral matching with the JHU mineral library providing a match with $(\boldsymbol{c})$ dolomite and $(\boldsymbol{d})$ olivine. $\boldsymbol{e}-\boldsymbol{h}$, Ground data collected from the field: $\boldsymbol{e}$, dolomite; $\boldsymbol{f}$, quartzite/siliceous rocks; $\boldsymbol{g}$, quartzite/ siliceous rock; $\boldsymbol{h}$, ultramafic rock.

matching of dolomite spectra in the carbonate region and olivine spectra in the ultramafic (Figure $7 c$ and $d$ ). Fieldcollected ground data clearly demarked the presence of ultramafic, siliceous and carbonate bodies in the thermally identified regions (Figure $7 e-h$ ).

\section{Conclusion}

ASTER data of Terra satellite have been successfully used to develop the regional scale outcrop pattern of ultramafics with the help of MRI-AV index. Besides this, the known occurrences of carbonate rocks hosting leadzinc mineralization have also been mapped and extrapolated, though the cyan colour distribution was not so accurate with the CI-N index. Siliceous rocks identified in the study are also important as they are suggestive of distribution of granitoids. The QRI-AV, QI-RH and QI-N indices applied for the identification of these rocks played a unique role as thin bands parallel to the carbonates were also mapped. RGB image of the study area was generated using the siliceous, ultramafic and carbonate outcrop patterns. 
Conflicts of interest: The authors declare that there is no conflict of interest.

1. Lyon, R. J. P., Infrared spectral emittance in geological mapping airborne spectrometer data from Pisgah Crater, California. Science, 1972, 175, 983-986.

2. Salisbury, J. W. and Walter, L. S., Thermal infrared $(2.5-13.5 \mu \mathrm{m})$ spectroscopic remote sensing of igneous rock types on particulate planetary surfaces. J. Geophys. Res., 1989, 94, 9192-9202.

3. Guha, A., Yamaguchi, Y., Chatterjee, S., Rani, K. and Vinod Kumar, K., Emittance spectroscopy and broadband thermal remote sensing applied to phosphorite and its utility in geoexploration: a study in the parts of Rajasthan, India. Remote Sensing, 2019, 11, 1003.

4. Kahle, A. B., Gillespie, A. R. and Goetz, A. F. H., Thermal inertia imaging: a new geologic mapping tool. Geophys. Res. Lett., 1976, 3, 419-421.

5. Salisbury, J. W. S. and D'Aria, D. M., Emissivity of terrestrial materials in the $8-14 \mu \mathrm{m}$ atmospheric windows. Remote Sensing Environ., 1992, 42, 83-106.

6. Guha, A. and Vinod Kumar, K., New ASTER derived thermal indices to delineate mineralogy of different granitoids of an Archaean craton and analysis of their potentials with reference to Ninomiya's indices for delineating quartz and mafic minerals of granitoids - an analysis in Dharwar Craton. Ore Geol. Rev., 2016, 74, 76-87.

7. Ninomiya, Y., Fu, B. and Cudahy, T. J., Detecting lithology with advanced spaceborne thermal emission and reflection radiometer (ASTER) multispectral thermal infrared 'radiance-at-sensor' data. Remote Sensing Environ., 2005, 99, 127-139.

8. Ding, C., Liu, X., Liu, W., Liu, M. and Li, Y., Mafic-ultramafic and quartz-rich rock indices deduced from ASTER thermal infrared data using a linear approximation to the Planck function. Ore Geol. Rev., 2014, 60, 161-173.

9. Ding, C., Li, X., Liu, X. and Zhao, L., Quartzose-mafic spectral feature space model: a methodology for extracting felsic rocks with ASTER thermal infrared radiance data. Ore Geol. Rev., 2015, 66, 283-292.

10. Rani, K., Guha, A., Pal, S. K. and Vinod Kumar, K., Comparative analysis of potentials of ASTER thermal infrared band derived emissivity composite, radiance composite and emissivitytemperature composite in geological mapping of Proterozoic rocks in parts Banswara, Rajasthan. J. Indian Soc. Remote Sensing, 2018, 46, 771-782.

11. Van der Meer, F. D. et al., Multi- and hyperspectral geologic remote sensing: a review. Int. J. Appl. Earth Obs. Geoinf., 2012, 14, 112-128.

12. Gillespie, A. R., Lithologic mapping of silicate rocks using TIMS In Proceedings of the Thermal Infrared Multispectral Scanner Data User's Workshop, Pasadena, CA, 1985, pp. 29-44.

13. Gupta, S. N. et al., The Precambrian geology of the Aravalli region, southern Rajasthan and north-eastern Gujarat. Mem. Geol. Surv. India, 1997, 123, 1-262.

14. Sinha-Roy, S., Malhotra, G. and Mohanty, M., Geology of Rajasthan, Geological Society of India, Bangalore, 1998.

15. Roy, A. B. and Jakhar, S. R., Geology of Rajasthan (Northwest India): Precambrian to Recent, Scientific Publishers (India), Jodhpur, 2002.

16. Bhu, H., Sarkar, A., Purohit, R. and Banerjee, A., Characterization of fluid involved in ultramafic rocks along the Rakhabdev Lineament from southern Rajasthan, northwest India. Curr. Sci., 2006, 91, 1251-1256.

17. Purohit, R., Bhu, H., Sarkar, A. and Ram, J., Evolution of the ultramafic rocks of the Rakhabdev and Jharol belts in southeastern Rajasthan, India: new evidences from imagery mapping, petrominerological and $\mathrm{OH}$ stable isotope studies. J. Geol. Soc. India, $2015, \mathbf{8 5}, 331-338$.

18. Abrams, M., The Advanced Spaceborne Thermal Emission and Reflection Radiometer (ASTER): data products for the high spatial resolution imager on NASA's Terra platform. Int. J. Remote Sensing, 2000, 21, 847-859.

19. Yamaguchi, Y., Kahle, A. B., Tsu, H., Kawakami, T. and Pniel, M., Overview of Advanced Spaceborne Thermal Emission and Reflection Radiometer (ASTER). IEEE Trans. Geosci. Remote Sensing, 1998, 36, 1062-1071.

20. Zhang, X., Pazner, M. and Duke, N., Lithologic and mineral information extraction for gold exploration using ASTER data in the south Chocolate Mountains (California). ISPRS J. Photogramm. Remote Sensing, 2007, 62, 271-282.

21. Gomez, C., Delacourt, C., Allemand, P., Ledru, P. and Wackerle, R., Using ASTER remote sensing dataset for geological mapping in Namibia. Phys. Chem. Earth, Parts $A / B / C, 2005,30,97-108$.

22. Kalinowski, A. and Oliver, S., ASTER Mineral Index Processing Manual, Remote Sensing Applications, Geoscience, Australia, 2004.

23. Matar, S. S. and Bamousa, A. O., Integration of the ASTER thermal infra-red bands imageries with geological map of Jabal Al Hasir area, Asir Terrane, the Arabian Shield. J. Taibah Univ. Sci., 2013, 7, 1-7.

24. Ninomiya, Y. and Fu, B., Regional lithological mapping using ASTER-TIR data: case study for the Tibetan Plateau and the surrounding area. Geosciences, 2016, 6, 39.

25. Rajendran, S. and Nasir, S., ASTER spectral sensitivity of carbonate rocks - study in Sultanate of Oman. Adv. Space Res., 2014, 53, 656-673.

26. Rowan, L. C., Mars, J. C. and Simpson, C. J., Lithologic mapping of the Mordor, NT, Australia ultramafic complex by using the Advanced Spaceborne Thermal Emission and Reflection Radiometer (ASTER). Remote Sensing Environ., 2005, 99, 105-126.

27. Ninomiya, Y. and Fu, B., Thermal infrared multispectral remote sensing of lithology and mineralogy based on spectral properties of materials. Ore Geol. Rev., 2019, 108, 54-72.

28. Pour, A. B. et al., Mapping listvenite occurrences in the damage zones of northern Victoria Land, Antarctica using ASTER satellite remote sensing data. Remote Sensing, 2019, 11, 1408.

29. Yao, K., Pradhan, B. and Idrees, M. O., Identification of rocks and their quartz content in Gua Musang goldfield using advanced spaceborne thermal emission and reflection radiometer imagery. J. Sensors, 2017, 2017, 6794095-1-6794095-8.

30. Rockwell, B. W. and Hofstra, A. F., Identification of quartz and carbonate minerals across northern Nevada using ASTER thermal infrared emissivity data-implications for geologic mapping and mineral resource investigations in well-studied and frontier areas. Geosphere, 2008, 4, 218-246.

31. Yajima, T. and Yamaguchi, Y., Geological mapping of the Francistown area in northeastern Botswana by surface temperature and spectral emissivity information derived from Advanced Spaceborne Thermal Emission and Reflection Radiometer (ASTER) thermal infrared data. Ore Geol. Rev., 2013, 53, 134-144.

32. Son, Y. S., Kang, M. K. and Yoon, W. J., Lithological and mineralogical survey of the Oyu Tolgoi region, southeastern Gobi, Mongolia using ASTER reflectance and emissivity data. Int. J. Appl. Earth Obs. Geoinf., 2014, 26, 205-216.

ACKNOWLEDGEMENTS. We acknowledge the USGS Earth Explorer for providing the ASTER-TIR data for this study. We thank the Space Applications Centre, Indian Space Research Organization, Ahmedabad for providing financial support (EPSA/GHCAG/GSD/ WP/15/2017), and the Head, Department of Geology, M. L. Sukhadia University, Udapur for providing the necessary facilities to conduct this study. We also thank the anonymous reviewer for a careful reading and providing constructive comments that helped us to improve the manuscript.

Received 4 April 2020; revised accepted 19 June 2020 